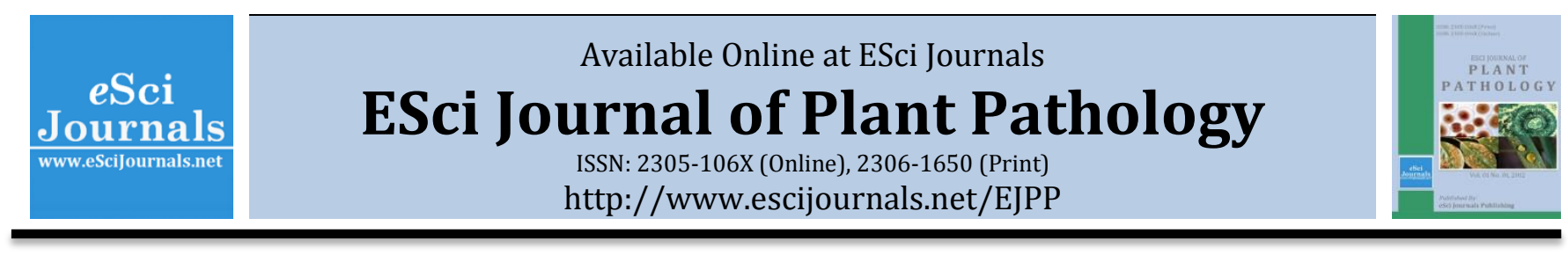

\title{
COMPLETE GENOME SEQUENCE OF TOMATO SPOTTED WILT VIRUS FROM PAPRIKA IN KOREA
}

\author{
aJae-Hyun Kim, bYoung-Soo Kim, aSoo-Won Jang, bYong-Ho Jeon* \\ a Ginseng Resources Research Laboratory, KGC Corp., Daejeon 305-805, Republic of Korea. \\ b Department of Bioresource Sciences, Andong National University, Andong 760-749, Republic of Korea.
}

\section{A B S T R A C T}

We isolated tomato spotted wilt virus (TSWV-KP) from a diseased Capsicum annuum var. grossum with malformed leaves and necrotic spotted fruits. TSWV-KP produced necrosis or necrotic ring spots on inoculated leaves along with mosaic, vein necrosis, or death on the upper leaves on Datura stramonium, Nicotiana clevarandii, $N$. rustica, and $N$. tabacum cvs. Ultrastructurally, typical tospovirus particles were observed in the cytoplasm. The virion contained three molecules of genomic RNAs of approximately 9.0, 4.9, and $3.0 \mathrm{~kb}$. The nucleocapsid (N) protein of the purified virion migrated as a single band with $\sim 29 \mathrm{kDa}$ molecular weight in SDS-PAGE. Complete nucleotide sequences of the large (L) genome segments of TSWV-KP were determined. Defective forms of L-RNA containing core polymerase regions were observed. L-RNA $(8,917$ nucleotides) contained a single open reading frame (ORF) in the viral complementary (vc) strand and encoded a 330-kDa protein. The L-protein had high identity in the "core-polymerase domain" with the corresponding regions of other tospoviruses. The complete nucleotide sequence of TSWV-KP medium-sized (M) RNA comprised 4,768 nucleotides and indicated a typical tospovirus with two genes in ambisense arrangement. The vRNA OFR coded for a potential cell-to-cell movement (NSm) 34.8-kDa protein; and the vcRNA ORF, for the viral glycoprotein (G1/G2) 128.0-kDa precursor. Multiple sequence alignment of the M-RNA showed highest homologies to TSWV-BR01. Amino acid sequences of TSWV-KP NSm and G1/G2 exhibited 48.7-85.3\% and 34.9-96.2\% identity, respectively. TSWV-KP small (S) RNA comprised 2,991 nucleotides with ambisense coding strategy. The sequence contained two ORFs-one in the viral sense, encoding a protein with predicted 52.4-kDa Mr; and another in the viral complementary sense, encoding the viral nucleocapsid protein of 28.8-kDa Mr. Amino acid sequences of TSWV-KP of S-RNA NSs and N exhibited $35.9-87.9 \%$ and $19.9-98.4 \%$ identity, respectively.

Keywords: Bunyaviridae, Tospovirus: Tomato spotted wilt virus, paprika, genome structure.

\section{INTRODUCTION}

Thus far, 13 species of the genus Tospovirus have been reported worldwide. Tomato spotted wilt virus (TSWV) comprises enveloped spherical particles (diameter, about $80-110 \mathrm{~nm}$ ); these particles are attached to the endoplasmic reticulum. Nucleotide sequence and translational analyses showed that TSWV has a large negatively stranded genomic RNA (IRNA) (de Haan et al., 1991) and 2 ambisense RNAs-sRNA and mRNA (de Haan et al., 1990; Kormelink et al., 1992). TSWV transmission by thrips commonly occurs in temperate and subtropical regions throughout the world (Ie, 1970). TSWV is distributed worldwide and has a very broad

\section{* Corresponding Author:}

Email: yongbac@andong.ac.kr

(C) 2013 ESci Journals Publishing. All rights reserved. host range of approximately 900 plant species in 80 families (Goldbach and Peters 1994).

In pepper crops with TSWV infection, yellowing and chlorotic rings appear on leaves. The incidence of TSWV infection in pepper- and tomato-producing areas can be as high as 60\% (Greenough et al., 1990). Twenty-five species of weed, including Malva parviflora, Verbescina encelioides, Bidens pilosa, and Ipomoea congesta, are considered to be the main reservoirs of TSWV (Cho et al., 1986).

The analyses of purified viral particles show that the envelope is lipidic in nature. It surrounds 3 types of single-stranded RNA molecules: sRNA (2.9 kb), mRNA (5.4 kb), and lRNA (8.9 kb) (van Den Hurk et al., 1977; Mohamed 1981; de Haan et al., 1990, 1991). Four structural proteins with different molecular masses 
(28.8, 58, 78, and $331.5 \mathrm{kDa}$ ) are found in the viral particles. The $28.8-\mathrm{kDa}$ protein, named as the nucleocapsid $(\mathrm{N})$ protein, is tightly associated with the RNA genome, both together forming a stable pseudocircular structure, i.e., the nucleocapsid. These nucleocapsids with few copies (between 10 and 20) of the $311.4-\mathrm{kDa}$ protein-named as large (L) proteinform the interior of the viral particle. The 78- and 58$\mathrm{kDa}$ proteins named as G1 and G2, respectively, are glycosides. They are located on the viral particle surface, forming the spikes observed under the electron microscope (Mohamed et al., 1973; Tas et al., 1977; Mohamed 1981; van Poelwijk et al., 1993).

The complete nucleotide sequence of the genome of the TSWV Brazilian isolate, BR01, has recently been determined. The L-RNA segment has negative polarity (). Thus, the viral complementary strand $(+)$ has to be copied before the L-RNA segment can be read. A promoter sequence not coded by the virus is added in this transcription process. This promoter is necessary to start the translation process. The L-RNA viral complementary strand contains a single open-reading frame (ORF) (de Haan et al., 1990). This ORF codes for the RNA-polymerase RNA-dependent L protein (Adkins et al., 1995). Medium-sized (M) and small (S) RNA segments both have an ambisense codifying strategy. Each of them have two ORFs separated by a central intercistonic region rich in $\mathrm{A}-\mathrm{U}$ links and bent in the form of a curl. M-RNA encodes in the viral sense a nonstructural protein called NSm (33.6 kDa); and in the viral complementary sense, a precursor of the two glycoproteins. S-RNA encodes in the viral sense a nonstructural protein named NSs $(53.4 \mathrm{kDa})$; and in the viral complementary sense, the $\mathrm{N}$ protein. Recently, the genus Tospovirus has been classified into five serogroups based on the serological cross reactivity and sequence homology of the N protein. Serogroup I consists of TSWV (de Haan et al., 1990; Maiss et al., 1991), which reacts weakly with the antibodies to Serogroup II members [TSWV-B; Groundnut ringspot virus (GRSV) and Tomato chlorotic spot virus (TCSV)] (de Avila et al., 1993; Pang et al., 1993) and does not react with antibodies to Impatiens necrotic spot virus (INSV), which is a serogroup III member (Law et al., 1990).

The serogroup IV members, Groundnut bud necrosis virus (GBNV) and Watermelon silver mottle virus (WSMoV), are serologically distinct from the members of serogroups I, II, and III (Adam et al., 1993). The N protein of TSWV (serogroup I) showed 77-78\% sequence identity with GRSV and TCSV (serogroup II) (de Avila et al.,, 1993), 55\% sequence identity with INSV (serogroup III) (de Haan et al., 1992) and 33-35\% sequence identity with Peanut bud necrosis virus (PBNV) and WSMoV (serogroup IV) (Yeh and Chang 1995). In this study, we identified TSWV from diseased paprika (Capsicum annuum var. grossum) for the first time, and its complete genome sequence was determined and analyzed.

\section{MATERIALS AND METHODS}

Host range of TSWV-KP: Virus-infected leaves were homogenized in $0.01 \mathrm{M}$ sodium phosphate buffer $(\mathrm{pH}$ 7.0) containing $0.01 \mathrm{M}$ sodium sulfite and rubbed onto healthy indicator plant leaves with a wooden trowel, after dusting with 600 mesh carborundum. After inoculation, the test plants were immediately rinsed with tap water, and maintained for visual inspection of virus symptoms in the green house at $25 \pm 2^{\circ} \mathrm{C}$ for at least 3 weeks.

Electron microscopy: Leaf-dip preparation was prepared by crushing $\sim 0.1 \mathrm{~g}$ of virus-infected leaf tissue in a drop of $2 \%$ sodium phosphotungstic acid (pH 6.8) on a parafilm. Formavar-coated grids were made to float on the drops for $30 \mathrm{sec}$, and then drained with a piece of filter paper. For ultrathin sections, samples were embedded in LR-White medium by using a modification of the method described by Cho (2003). Systemically infected leaves were cut at $1 \times 3 \mathrm{~mm}$ and fixed in $3 \%$ glutaraldehyde in $0.01 \mathrm{M}$ cacodylate buffer for $2 \mathrm{~h}$. The fixed samples were washed 3 times in sodium phosphate buffered salts ( $\mathrm{pH} 7.2)$ and post-fixed with $2 \%$ osmium tetroxide for $2 \mathrm{~h}$ at $4{ }^{\circ} \mathrm{C}$ and dehydrated with an ascending series of $50-100 \%$ ethanol in 6 steps for 30 min each. The hydrated samples were embedded in LRWhite medium and polymerized at $60^{\circ} \mathrm{C}$ for $24 \mathrm{~h}$. Ultrathin sections of 80-nm thickness were stained with $2 \%$ uranyl acetate and $0.5 \%$ lead citrate and rinsed with distilled water. The leaf-dip preparation and ultrathin sections were viewed and photographed using a Zeiss LEO 906 transmission electron microscope at $80 \mathrm{kV}$.

Purification of virions: The nucleocapsid of TSWV was purified by a modification of the method previously described (Tsuda et al., 1992). All work was performed on ice. Batches of $100 \mathrm{~g}$ of TSWV-infected N. rustica leaves were homogenized for $5 \mathrm{~min}$ in a blender at a high speed with $0.1 \mathrm{M}$ Tris- $\mathrm{HCl}(\mathrm{pH} 7.0 ; 1: 5, \mathrm{w} / \mathrm{v})$ containing $10 \mathrm{mM}$ sodium sulfite, $10 \mathrm{mM}$ glycine, $0.1 \%$ 
(w/v) L-cysteine and Triton X-100. These were centrifuged at $10,000 \times g$ for $10 \mathrm{~min}$. Then, $5 \%$ polyethylene glycol (mol. wt., 8,000) and $0.2 \mathrm{M} \mathrm{NaCl}$ was added to the supernatant. The precipitate after centrifugation at 7,500 $\times \mathrm{g}$ for $10 \mathrm{~min}$ was resuspended with $10 \mathrm{mM}$ Tris- $\mathrm{HCl}(\mathrm{pH} 7.0$ ) containing $1 \mathrm{mM}$ glycine, and then centrifuged at $65,000 \times g$ for 120 min through a $20 \%$ sucrose cushion. The pellets were resuspended in $10 \mathrm{mM}$ Tris-HCl (pH 7.0) containing $1 \mathrm{mM}$ glycine and further purified by centrifugation in $20-50 \%$ sucrose density gradient at 77,000 $\times \mathrm{g}$ in a Beckman SW28 rotor for $3 \mathrm{~h}$. The opalescent zones containing virus nucleocapsids were collected, further centrifuged at $130,000 \times g$ for $90 \mathrm{~min}$, and finally resuspended in 10 $\mathrm{mM}$ Tris- $\mathrm{HCl}(\mathrm{pH}$ 7.0) as purified nucleocapsids.

SDS-polyacrylamide gel electrophoresis: The molecular weight of the coat protein for the purified viruses of TSWV was determined by sodium dodecyl sulfate polyacrylamide gel electrophoresis (SDS-PAGE). The purified virus $(1 \mathrm{mg} / \mathrm{ml})$ was mixed with equal volumes of sample buffer (0.125 M Tris-HCl, $\mathrm{pH} 6.8,20 \%$ glycerol, 4\% SDS, 10\% ß-mercaptoethanol, and 0.002\% bromophenol blue) and then heated for $3 \mathrm{~min}$ at $100^{\circ} \mathrm{C}$. The sample was electrophoresed at $100 \mathrm{~V}$ for $1 \mathrm{~h}$ by using a $4 \%$ stacking gel on a $12 \%$ discontinuous polyacrylamide slab gel containing $0.1 \%$ SDS following the method of Laemmli and Farre (1973). After the electrophoresis, the gel was stained with Coomassie brilliant blue R 250 .

Isolation of viral dsRNAs: The isolation procedure of dsRNAs from the virus-infected $N$. rustica was similar to that described by Morris and Dodds (1979). The dsRNAs were eluted from the CF-11 cellulose column and precipitated by ethanol and sodium acetate. The pellet was washed with $80 \%$ ethanol, dried under vacuum, and then dissolved in RNase-free water. Total dsRNAs were loaded on $0.8 \%$ agarose gel and separated by electrophoresis. The dsRNAs bands were visualized under ultraviolet light.

Extraction of viral RNA from partially purified virions: All materials and solutions used for RNA isolation were sterilized by autoclaving, backing, filtering, or treating with diethyl pyrocarbamate (DEPC) solution prior to use. All samples were kept on ice and all centrifugation steps were performed at $4^{\circ} \mathrm{C}$. Viral RNA was extracted from the purified virions by using a modification of the method described by Ryu et al., (1995). Equal volumes of the virus $(0.5 \mathrm{mg} / \mathrm{ml})$ and extraction solution (100 mM Tris- $\mathrm{HCl}, \mathrm{pH} 7.6,20 \mathrm{mM}$ EDTA, $100 \mathrm{mM} \mathrm{NaCl}, 2 \mathrm{mM}$ DTT, 1\% SDS) were mixed, and proteinase $\mathrm{K}$ was added to the final concentration of $100 \mu \mathrm{g} / \mathrm{ml}$. It was mixed by gentle agitation and incubated at $37^{\circ} \mathrm{C}$ for $45 \mathrm{~min}$. Equal volumes of a phenol/chloroform/isoamylalcohol mixture (PCI, $25: 24: 1, v / v / v)$ were added, and the sample was vortexed and centrifuged at 14,000 rpm for $20 \mathrm{~min}$. The aqueous phase was carefully collected and kept on ice. The PCI extraction was then repeated. The final aqueous phase was recovered and re-extracted once with chloroform:isoamylalcohol (CI, 24:1, v/v). The viral RNA was precipitated with half volume of $7.5 \mathrm{M}$ ammonium acetate and 2.5 volumes of cold absolute ethanol. This mixture was stored at $-70^{\circ} \mathrm{C}$ for $2 \mathrm{~h}$. After centrifugation at $14,000 \mathrm{rpm}$ for $20 \mathrm{~min}$, the precipitate of viral RNA was rinsed with $80 \%$ ice-cold ethanol and centrifuged at $14,000 \mathrm{rpm}$ for $10 \mathrm{~min}$. The pellets were dried in a Speedvac for $5 \mathrm{~min}$ and then suspended in $50 \mu \mathrm{l}$ of DEPC-treated distilled water. This was divided into small aliquots, and stored at $-70^{\circ} \mathrm{C}$.

Rapid amplification of cDNA end (RACE): A $5^{\prime}$-end cDNA synthesis was performed according to the methods described in the GIBCO BRL Protocols and Applications Guide. For first strand synthesis, approximately 1.5-3.0 $\mu \mathrm{g}$ (total volume, $20 \mu \mathrm{l}$ ) of each viral RNA of TSWV-KP was denatured for 2 min at $70^{\circ} \mathrm{C}$ in a reaction volume containing $1 \mu$ l of gene-specific primer (GSP), SMART II oligo (5'CGTATCTCACCCTGTCGGCGCTC-3'), and $5 \mu \mathrm{l}$ of $\mathrm{dH}_{2} \mathrm{O}$. After cooling on ice for $10 \mathrm{~min}$, the following first strand cDNA synthesis mixture [ $1 \times$ first strand reaction buffer, $0.5 \mathrm{mM}$ DTT, $1 \mathrm{mM}$ dNTP, 0.8 units RNase inhibitor, 0.2 units AMV (TaKaRa)] was added and incubated at $42^{\circ} \mathrm{C}$ for $1 \mathrm{~h}$. For amplification of cDNA, $48 \mu \mathrm{l}$ of the PCR reaction mixture $[1 \times$ Taq polymerase buffer (TaKaRa), 2 $\mathrm{mM}$ dNTP, $5 \mathrm{mM} \mathrm{MgCl}_{2}, 0.5 \mu \mathrm{M}$ Universal primer mix (UPM; Clontech), $0.1 \mu \mathrm{M}$, GSPs (TSWV-KP TFR 10, TMR 6, and TSR 4), and EX-Taq DNA polymerase (TaKaRa)] was added to the $2 \mu \mathrm{l}$ of the first strand cDNA solutions. PCR cycling consisted of $94^{\circ} \mathrm{C}$ for $40 \mathrm{sec}, 52^{\circ} \mathrm{C}$ for $40 \mathrm{sec}$, and $68^{\circ} \mathrm{C}$ for $10 \mathrm{~min}$ ( 35 cycles). The last cycle was followed by a prolonged extension for $20 \mathrm{~min}$ at $68^{\circ} \mathrm{C}$ to complete synthesis of the cDNA products. The amplified DNAs were purified for nucleotide sequence determination.

Polyadenylation of viral RNA and amplification of full-length Cdna: Genomic RNA of viruses in the 
tospovirus contains a nopoly (A) tract in the $3^{\prime}$-end. To produce cDNA by reverse transcription from the $3^{\prime}$ terminal of TSWV, genomic RNAs were polyadenylated at their $3^{\prime}$ ends in vitro by the method of Sippel (1973). Approximately 3.0-5.0 $\mu \mathrm{g}$ (in $50 \mu \mathrm{l}$ ) of viral RNA of TSWV-KP were incubated at $75^{\circ} \mathrm{C}$ for $90 \mathrm{sec}$ for denaturation and quickly chilled on ice. After cooling on ice for $10 \mathrm{~min}$, the polyadenylation mixture [0.8 units RNase inhibitor (TaKaRa), $0.5 \mathrm{M}$ Tris-HCl, pH 8.0, containing $25 \mathrm{mM} \mathrm{MnCl} 2,10 \mathrm{mM}$ DTT, $10 \mathrm{mM}$ ATP (Roche), and $2 \mu \mathrm{l}$ of E. coli poly (A) polymerase (7 units, GIBCO BRL)] was added directly to the denatured viral RNAs and incubated at $37^{\circ} \mathrm{C}$ for $20 \mathrm{~min}$. After incubation, the polyadenylation reaction was terminated by adding $\mathrm{Na}_{2}$-EDTA solution ( $\mathrm{pH}$ 8.0) to the final concentration of $10 \mathrm{mM}$.

The reaction mixture was extracted once with PCI and once with CI. Half volume of 7.5 M ammonium acetate was added to the supernatant and precipitated with 3 volumes of absolute ethanol. The resulting pellets of viral RNAs were dissolved in $10 \mu \mathrm{l}$ volumes of DEPCtreated RNase-free water. Primers for full-length sequencing of TSWV-KP were designed corresponding to TSWV-BR01 (L RNA [NC_002052], M-RNA [NC_002050], and S-RNA [NC_002051]), respectively. RT-PCR was carried out with primer pairs from viral RNA extracted from purified virus particles by SDS-phenol extraction methods. The relative position of the pairs in the TSWV genomes is schematically shown in Fig. 2, and each PCR product is used as a template for sequencing.

RT-PCR was performed in the same tube containing 50 $\mu \mathrm{l}$ reaction mixture containing $500 \mathrm{ng}$ of purified viral RNA, $10 \mu \mathrm{l} 5 \times$ reaction buffer, $10 \mathrm{ng}$ each of reverse primer and forward primer, $1 \mathrm{mM}$ deoxynucleotide triphosphate (dNTP), 10 units of RNase inhibitor, 10 units of AMV reverse transcriptase (TaKaRa), and 5 units of Ex Taq polymerase (TaKaRa). The RT-PCR cycle was as follows: $50^{\circ} \mathrm{C}, 45 \mathrm{~min} ; 94^{\circ} \mathrm{C}, 2 \mathrm{~min}(1 \mathrm{cycle}) ; 94^{\circ} \mathrm{C}, 30$ sec; $50-55^{\circ} \mathrm{C}, 30 \mathrm{sec} ; 72^{\circ} \mathrm{C}, 2 \mathrm{~min}(40$ cycles $)$; and $72^{\circ} \mathrm{C}$, $10 \mathrm{~min}$. The synthesized RT-PCR products were directly analyzed on $1 \%$ agarose gel with a $1-\mathrm{kb}$ DNA ladder (Promega). Each template was purified by MicroSpin TM S-400 H Columns (Amersham Biosciences).

Full-length cDNAs were sequenced by using ABI PRISM BigDye $^{\mathrm{TM}}$ Terminator v. 3.0 Cycle Sequencing Kits (Roche) directly with the eight templates and designed primers. Sequencing reactions were run on a fluorescent
DNA sequencer ABI3100 (Perkin-Elmer). Sequences were analyzed by using the Sequencer program (Gene Code Corporation, USA). Analyses of nucleotides and the deduced amino acid sequences of TSWV-KP were performed by using the DNAStar (Medision, WI, USA) and DNAman Sequence Analysis Program (Version 5.1, Lynnon Biosoft Co., Canada). The nucleotide and amino acid sequences of TSWV-KP and TSWV-BR01 and those of other viruses of Tospovirus group were surveyed by using Genbank (http://www.ncbi.nih.gov).

\section{RESULTS}

Symptomatology and host range: TSWV-infected paprika crops showed mosaic and, at times, necrotic spots on the upper leaves. Infected fruits had generally large chlorotic or necrotic spots and were not commercially viable (Fig. 1-A). Inoculated leaves of $N$. rustica showed necrotic lesions with chlorotic rings, followed by systemic mosaic and necrotic spots. Chlorotic local lesions on the inoculated leaf of $N$. benthamiana appeared 4-5 d after inoculation, followed by yellowing. Petunia hybrida and Gomphrena globosa showed necrotic local and white necrotic local lesions on inoculated leaves 3-4 d after inoculation, respectively. $N$. tabacum cv. White burley and cv. Ky-57 showed local lesions on the inoculated leaves with systemic symptoms. Finally, all the plants died with severe necrosis (Table 1 ).

Cytology of TSWV-infected pepper leaf tissue: In ultrathin sections of the tissue of $C$. annuum infected with TSWV-KP, the virus particles of TSWV-KP accumulated in the cistae of endoplasmic reticulum (ER). Single-enveloped virions (SEV) were present in the cytoplasm. SEV concentration in leaf tissue was abundant; further, double-enveloped virions as well as fiber and fibrous structures could also be found in most parts of the cytoplasm of the infected cells (Fig. 1-B).

Molecular weight of $\mathbf{N}$ protein: The nucleocapsid of TSWV-KP was purified from $N$. rustica plants that showed typical tospovirus symptoms. The preparation, analyzed by SDS-PAGE, gave a single protein band (Fig. 1-C, left). The N protein of the TSWV-N, TSWV-M, and TSWV-P isolates had a molecular weight of $30 \mathrm{kDa}$, while the molecular weight of the TSWV-W and TSWV-K isolates was $32 \mathrm{kDa}$ (Tsuda et al., 1996). The molecular size pattern of TSWV-KP was similar to those of the Japanese isolates of $\mathrm{N}, \mathrm{M}$, and $\mathrm{P}$ of TSWV.

Analysis of dsRNAs: The total dsRNA segments extracted from the leaves of $N$. rustica infected with 

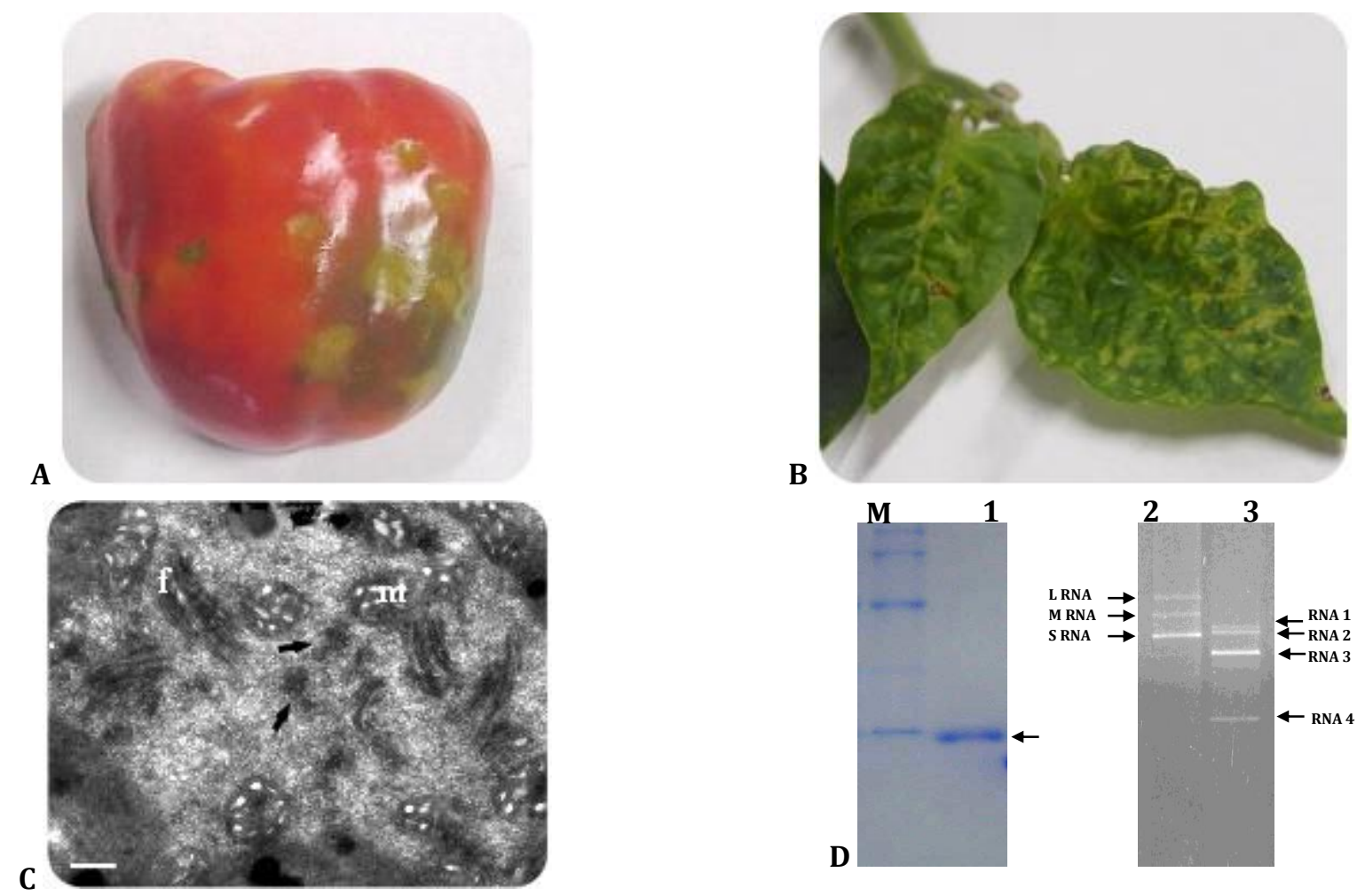

Figure 1. Symptoms, cytology, N protein and dsRNAs analysis of TSWV-KP. A, Large chlorotic and necrotic spots on the fruit, severe mosaic and malformation on the leaves of paprika. B, Ultrastructure of the tissue of $C$. annuum infected with TSWV-KP. Formation of single enveloped virion (arrows) by fusion of double enveloped virion. f, filamentous inclusion; m, mitochondria. Bars, 300nm. C, Electrophoresis of coat protein and genomic RNA of TSWV-KP. M, standard protein; 1, The purified nucleocapsid protein; 2, TSWV dsRNAs; 3, CMV-Mf dsRNAs.

\section{RNA}

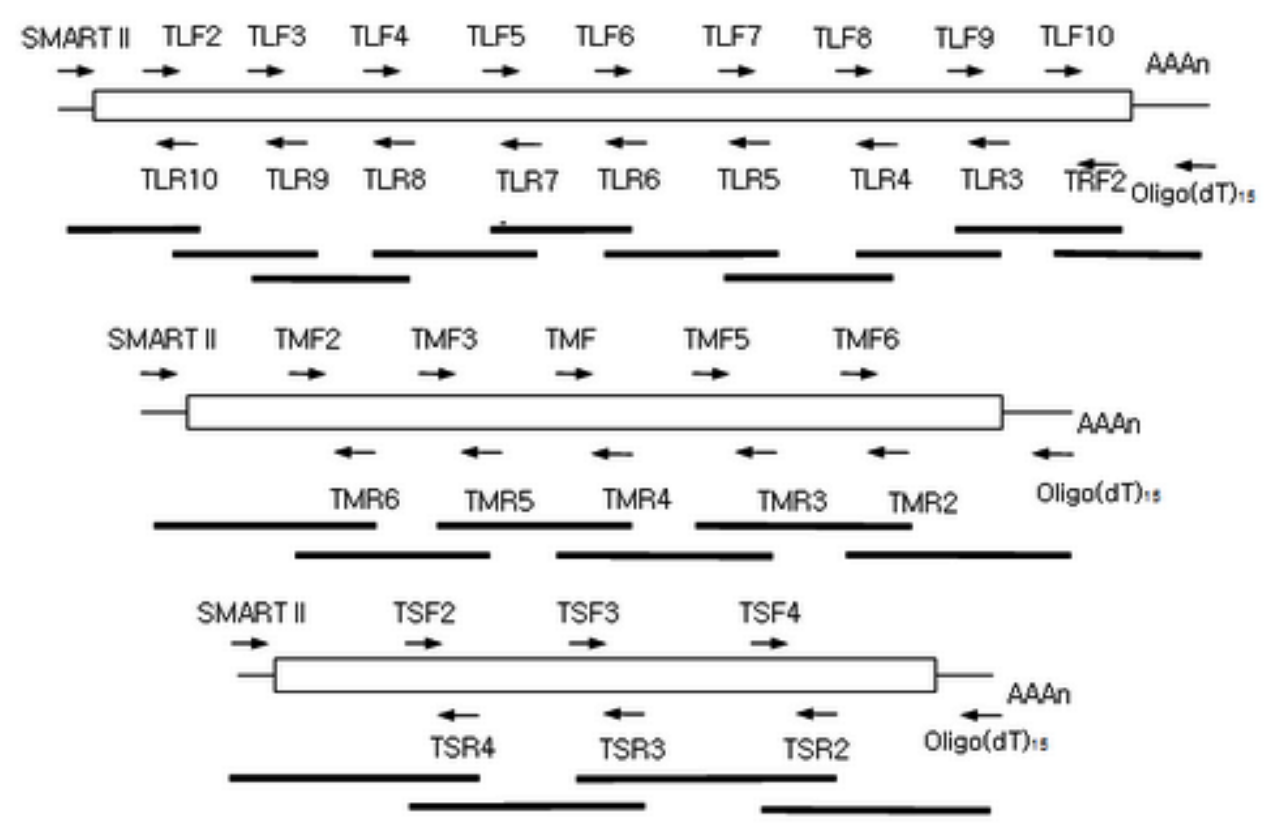

Figure 2. Schematic representation of nucleotide sequencing strategy for TSWV-KP L RNA, M RNA and S RNA. Horizontal lines represent templates for sequencing. Arrows represent the sequencing position and orientation of each primers. 
TSWV-KP were analyzed by electrophoresis in $0.8 \%$ agarose gel. A typical dsRNA virus is shown in Figure 1$\mathrm{C}$, right side (lane 2). The dsRNAs extracted from CMVinfected tobacco were used as markers (Fig. 1-C, lane 3). The sizes of the three dsRNAs of TSWV-KP were estimated to be $9.0 \mathrm{~kb}, 4.9 \mathrm{~kb}$, and $3.0 \mathrm{~kb}$. Based on the molecular size of the dsRNAs (Tsuda et al., 1992), they were considered the replication forms of genomic L-, M-, and S-RNA, respectively.

Sequence of L-RNA: The complete nucleotide sequence of the TSWV-KP L-RNA had 8,917 nucleotides, with a base composition of $37.7 \% \mathrm{~A}, 28.4 \% \mathrm{U}(\mathrm{T}), 14.7 \% \mathrm{C}$, and $19.6 \% \mathrm{G}$ (data not shown). The length was in very good agreement with the previously estimated size, deduced from electrophoretic mobility (Van den Hurk et al., 1977; de Haan et al., 1991a). It was similar to that of L-RNA of TSWV-BR01 (8,897 nt; NC_002052), INSV (8,776 nt; NC_003625), GBNV (8,911 nt; NC_003614), and WSMoV (8,917 nt; NC_3832).

Sequence analysis showed that the L-RNA of TSWV contained a single large ORF initiating at the ATG codon at nt position 34 and terminating at the TAA codon at $n t$ position 8,676 from the $5^{\prime}$ end of the viral strand. It was encoded in a protein comprising 2,880 amino acids with a predicted molecular weight of $330.9 \mathrm{kDa}$. No other reading frame in viral or viral complementary sense contained ORFs of significant size. Thus, the L-RNA of TSWV-KP appears as a negative-sense RNA (Fig. 3). The predicted size of the L-RNA protein was similar to that of TSWV-BR01. The identities in the nucleotide and amino acid sequence of the L protein exhibited $54.2-92.2 \%$ and $45.6-93.6 \%$ identity with other tospoviruses, respectively (Fig. 4).

The predicted translation product of the TSWV-KP LRNA appeared to be the viral polymerase. This is based on the similarities between the sequence and size of other tospovirus $\mathrm{L}$ proteins and the presence of conserved signature sequences in the "core polymerase region" (Fig. 5, A-E). This is a characteristic of the viral RNA polymerases of the negative-stranded Bunyaviridae (Poch et al., 1989).

Sequence of M-RNA: The M-RNA of TSWV-KP contains 4,768 nucleotides showing an ambisense arrangement typical of tospoviruses (Fig. 3). The M-RNA has a base composition of $31.7 \% \mathrm{~A}, 32.6 \% \mathrm{~T}(\mathrm{U}), 17.7 \% \mathrm{C}$, and $18.0 \% \mathrm{G}$ (data not shown). The ORF within the viral RNA strand starts with an ATG codon at nucleotide (nt) 101 and stops at a TAG triplet on nt 1,009 from the $5^{\prime}$ end of the viral sense RNA. It encoded a protein of 301 amino acids due to its homology with the same ORF of TSWVBR01, INSV, GBNV, and WSMoV M-RNA, which represented the potential role in cell-to-cell movement protein (NSm).

The ORF within the viral complementary strand of the RNA starts with an ATG at nt position 4,683 and stops with a TGA stop codon at nt position 1,276 from the 5' end of the viral sense RNA. It encodes for the precursor to the glycoproteins G1 and G2, and encompasses 1,134 amino acids.

The complete sequence of TSWV-KP M-RNA allowed for comparison among the six tospovirus M-RNA sequences. The homologies for the TSWV-KP NSm protein were higher than those of TSWV-BR01 and INSV but lower than those of GBNV and WSMoV (Table 2).

Moreover, higher homologies were noted throughout the NSm protein for all tospoviruses (40-70\%), with the exception of the first $60 \mathrm{~N}$-terminal amino acids (Fig. 6). The "D-motif" found in the "30K-superfamily" of virus movement proteins (Melcher 2000; Mushegian et al., 1993) was also present in all the NSm amino acid sequences of Brazilian tospoviruses as well as in TSWV, INSV, GBNV, and WSMoV (Fig. 6).

In addition to the "D-motif," the "P/D-L-X motif" and a glycine residue ("G-residue") that were almost completely conserved in the C-termini of several movement proteins from the " $30 \mathrm{~K}$ superfamily" (Melcher 2000) were also present in NSm sequences (Fig. 6). While the "P/D-L-X motif" was present only in GRSV, TCSV, CSNV, TSWV, and INSV, the "G-residue" was present in all NSm sequences except in INSV.

In addition to the typical " $30 \mathrm{~K}$ superfamily" motifs, a homologous region to the phospholipase A2 (PLA2) catalytic site was observed only in GRSV, TCSV, CSNV, and TSWV, i.e., viruses that had a relatively broad host range (Fig. 6). In some PLA2 catalytic sites, there was a histidine residue at the center and three cysteine residues involved in disulphide bonds at the edges (Dennis 2005; Silva et al., 2001). A different amino acid pattern was present in TSWV-KP and BR-01 NSm sequences (Fig. 6).

Sequence of S-RNA: The complete nucleotide sequence of the TSWV-KP S-RNA comprised 2,991 nucleotides. This was similar to the size estimated by relative electrophoretic migration in denaturing agarose gels (Mohamed 1981). It had a base composition of $32.0 \% \mathrm{~A}$, $33.8 \% \mathrm{U}, 18.4 \% \mathrm{C}$, and $15.8 \% \mathrm{G}$. 
ESci J. Plant Pathol. 02 (03) 2013. 121-136

Table 1. Symptoms on indicator plant species induced by TSWV-KP isolate.

\begin{tabular}{|c|c|c|c|}
\hline \multirow{2}{*}{\multicolumn{2}{|c|}{ Indicator plants }} & \multicolumn{2}{|c|}{ Host reaction $^{\mathrm{a}}$} \\
\hline & & Inoculated leaves & Upper leaves \\
\hline \multicolumn{2}{|c|}{ Chenopodium amaranticolor } & $\mathrm{NL}$ & - \\
\hline \multicolumn{2}{|c|}{ C. quinoa } & NL & - \\
\hline \multicolumn{2}{|c|}{ Gomphrena globosa } & CWL & - \\
\hline \multicolumn{2}{|c|}{ Physalis floridana } & NL & - \\
\hline \multicolumn{2}{|c|}{ Datura stramonium } & NR & NS \\
\hline \multicolumn{2}{|c|}{ Nicotiana benthamiana } & CS & M \\
\hline \multicolumn{2}{|c|}{ N. glutinosa } & NL & - \\
\hline \multicolumn{2}{|c|}{ N. clevarandii } & NS & NS \\
\hline \multicolumn{2}{|c|}{ N. rustica } & NR & NS \\
\hline \multirow[t]{4}{*}{ N. tabacum } & cv. Xanthi nc. & NS & NS \\
\hline & cv. White burley & NS & VN, LD \\
\hline & cv. Ky-57 & NS & VN, LD \\
\hline & cv. Samsun & NS & VN, LD \\
\hline \multicolumn{2}{|c|}{ Petunia x hybrida } & NL & - \\
\hline \multicolumn{2}{|c|}{ Lycopersicon esculentum } & + & M \\
\hline
\end{tabular}

a -, no infection; +, latent symptom; CS, chlorotic spot; CWL, chlorotic white lesion; LD, lethal death; M, mosaic; NL, necrotic local infection; NR, necrotic ring; NS, necrotic spot; VN, vein necrosis.

Table 2. Identities of nucleotide sequence (nt), amino acid (aa) of TSWV-KP M RNA and those of other tospoviruses.

\begin{tabular}{|c|c|c|c|c|c|c|c|}
\hline \multirow{2}{*}{ Virus $^{\mathrm{a}}$} & \multirow{2}{*}{$5^{\prime} \mathrm{UTR}$} & \multicolumn{2}{|c|}{$\mathrm{NSm}$} & \multirow{2}{*}{ IGR } & \multicolumn{2}{|c|}{ G1/G2 } & \multirow{2}{*}{$3^{\prime} \mathrm{UTF}$} \\
\hline & & nt & aa & & nt & aа & \\
\hline TSWV-BR01 & 97.1 & 92.3 & 85.3 & 90.3 & 93.4 & 96.2 & 92.0 \\
\hline GRSV & - & - & - & - & 74.8 & 81.1 & 80.5 \\
\hline TCSV & - & - & - & - & 74.6 & 79.9 & 80.5 \\
\hline INSV & 54.5 & 67.8 & 66.1 & 50.4 & 65.2 & 63.9 & 56.8 \\
\hline GBNV & 64.8 & 40.6 & 51.3 & 45.9 & 49.0 & 35.1 & 54.2 \\
\hline WSMoV & 64.2 & 37.3 & 48.7 & 45.0 & 48.8 & 34.9 & 54.2 \\
\hline
\end{tabular}

aThe following sequences were obtained from NCBI GenBank database. TSWV-BR01 [NC_002050], GRSV [AY574055], TCSV [AY574054], INSV [NC_003616], GBNV [NC_003620], WSMoV [NC_003841].

The $5^{\prime}$ and $3^{\prime}$ ends of the viral RNA contained two untranslated regions of 88 and $151 \mathrm{nt}$, respectively, with 58-nt complementary sequences at the terminal which could form a strong panhandle structure characteristic of the members of Bunyaviridae (data not shown). The sequence analysis of TWSV-KP S-RNA revealed two ORFs with an ambisense arrangement (Fig. 3).

There was a large ORF of 1,404 nt located on the $5^{\prime}$ end of the viral sense strand. This was initiated with an AUG codon at nucleotide 89 and terminated at an UAA stop codon at nucleotide 1,492 from the $5^{\prime}$ end of the viral strand. This ORF encoded a 468 amino acid polypeptide with a predicted $\mathrm{Mr}$ of 52,446. Another ORF was located near the $5^{\prime}$ end of the viral complementary strand, initiating with the AUG codon at nucleotide 2,840 and terminating at the UAA stop codon at nucleotide 2,064 from the $5^{\prime}$ end of the viral strand. This ORF could encode a protein of 258 amino acids with a predicted $\mathrm{Mr}$ of $28.8 \mathrm{kDa}$, which was the $\mathrm{N}$ protein based on the sequence comparison to the $\mathrm{N}$ proteins of other tospoviruses.

The ORFs coding for NSs and N proteins were separated by a 571-nt A+U-rich intergenic region (IGR). Size differences between the S-RNA molecules of different tospovirus isolates have been attributed to the variation in length of the intergenic region. 
L RNA Strand RF $\frac{\text { START }}{\text { STOP }}$
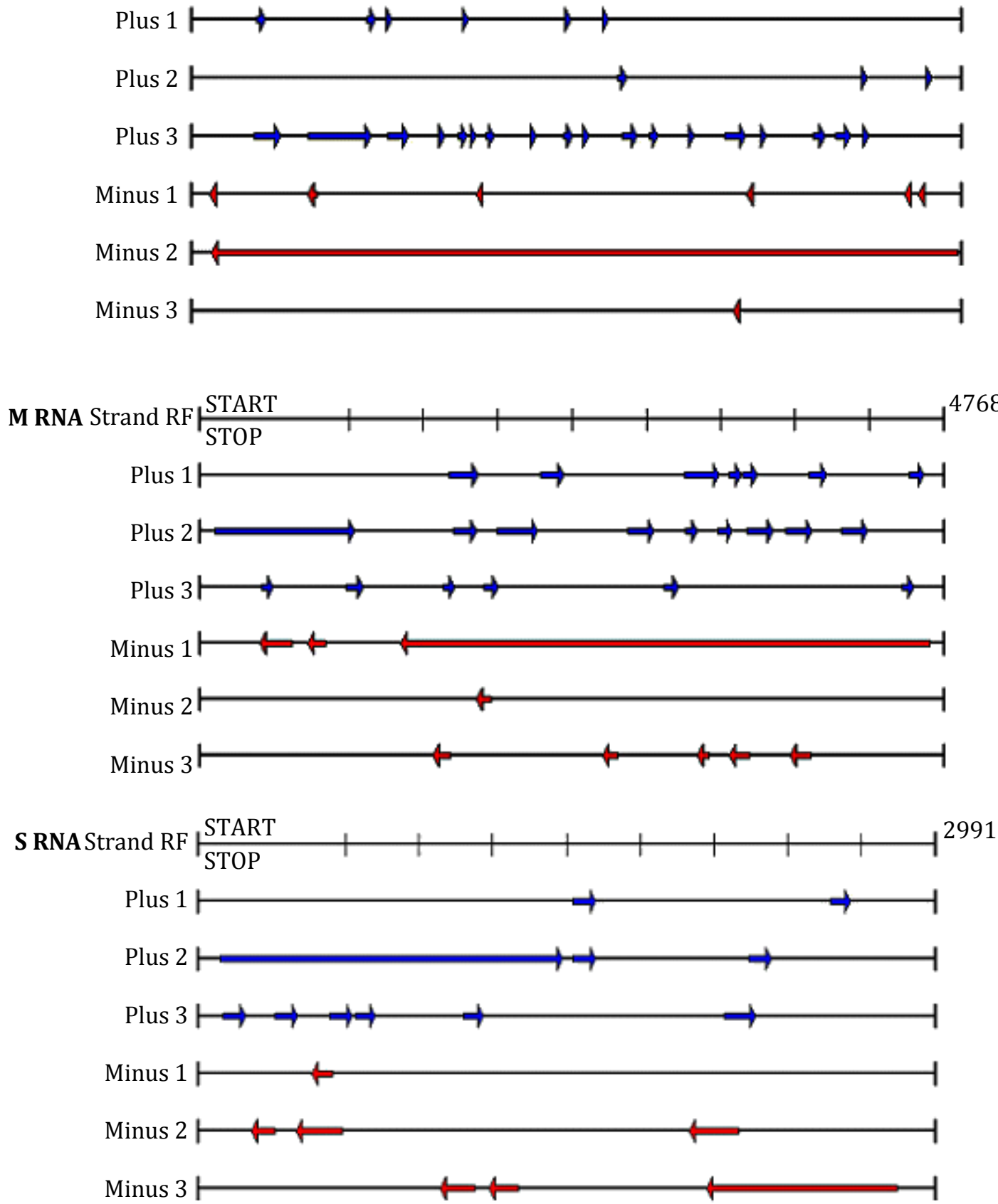

Figure 3. Distribution of open reading frame (ORF) in the three possible reading frames of the viral (a,2, and 3$)$ and viral complementary (-1,-2 and -3) L, M and S RNA strands of TSWV-KP.

The identity values based on the amino acids and sequences of tospovirus $\mathrm{N}$ and NSs proteins were completely consistent with the known serological grouping.

The identities in the nucleotide and amino acid sequences of TSWV-KP N protein exhibited $38.2-96.4 \%$ and $19.9-98.4 \%$ identity with those of tospovirus serogroups I-V. This value is in contrast to the 77.5$79.8 \%$ identity reported for serotype II, $54.5 \%$ identity observed with serotype III, $31.1 \%$ and $41.5 \%$ identity reported with serotype IV, and $19.9 \%$ identity observed with serotype $\mathrm{V}$ (Table 3). Thus, $\mathrm{N}$ protein TSWV-KP appears to represent the most closely related serotype I member of the genus Tospovirus (Fig. 7). 


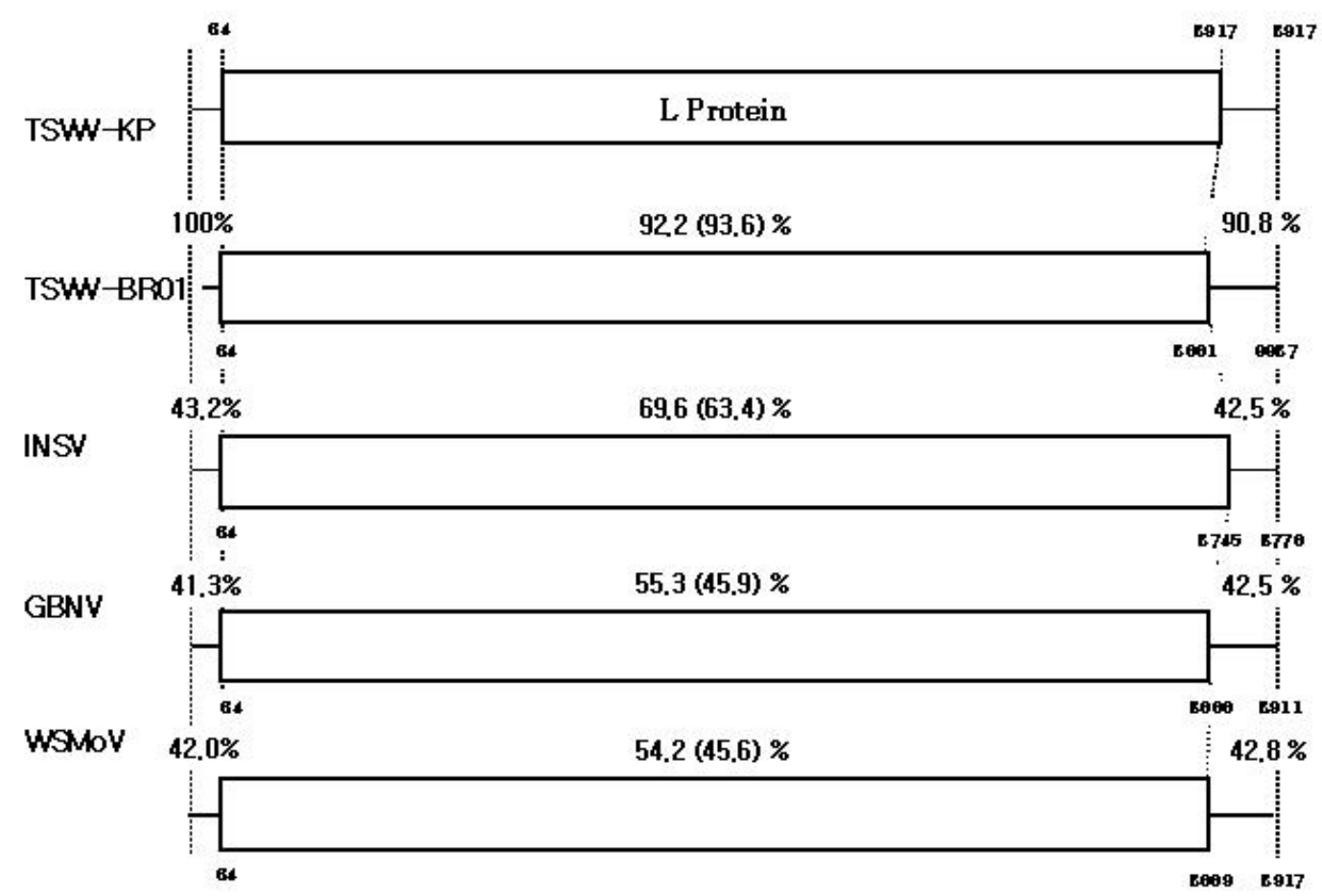

Figure 4. Comparison of the genomic L RNA molecules of TSWV-KP and other tospovirus (numbered from the 5 'end of the vRNAs). The percentages refer to nucleotide and amino acid sequences homology between the various UTR and L protein domains.

\begin{tabular}{|c|c|c|c|}
\hline & MOTIF A & \multicolumn{2}{|c|}{ MOTIF B } \\
\hline TSWV-KP & KKSRIAFLSADQSKWS & \multicolumn{2}{|c|}{ TTNTYPVSMNWLQGNLNYLSSVYH } \\
\hline INSV & NKSKIAFLSADQSKWS & \multicolumn{2}{|c|}{ STNSYPVSMNWLQGNLNYLSSVYH } \\
\hline GBNV & LECKMAFLSADQSKWS & \multicolumn{2}{|c|}{ ETNTFPVSMNWLQGNLNYLSSVYH } \\
\hline WSMoV & LECKMAFLSADQSKWS & \multicolumn{2}{|c|}{ ETNTFPVSMNWLQGNLNYLSSVYH } \\
\hline BUNV & . KALKLEINADMSKWS & \multicolumn{2}{|c|}{ AQ.DVFYKYNWLQGNFNYTSSYVH } \\
\hline RVFV & .PVWTCATSDDARKWN & \multicolumn{2}{|c|}{.QGHFVTKFGMMQGILHYTSSLLH } \\
\hline HTNV & .KRKLMYVSADATKWS & \multicolumn{2}{|c|}{ P.GDNSAKFNWLQGNLNKCSSLFG } \\
\hline PUUV & .KRKLMYVSADATKWS & \multicolumn{2}{|c|}{ P. GDNSAKFNWLQGNLNKCSSLFG } \\
\hline & MOTIF C & MOTIF D & MOTIF E \\
\hline TSWV-KP & IVHSDDNATSLI & ITLNPKKSYASSSE & SSEV.EFIE \\
\hline INSV & IVHSDDNATSLI & ITLNPKKSYASSSE & SSEV.EFIS \\
\hline GBNV & MVHSDDNATSLI & ITLNPKKSYASESE & ESEV.EISE \\
\hline WSMoV & MVHSDDNATSLI & ITLNPKKSYASESE & ESEV.EISE \\
\hline BUNV & MVHSDDNQTSLA & CQANMKKTYITHTC & HTCK. EFVS \\
\hline RVFV & MQGSDDSSMLIS & IYPSEKSTANTDFV & TDFVMEYNS \\
\hline HTNV & AHHSDDALFIYG & IKISPKKTTVSPTN & PTNA.EFLS \\
\hline PUUV & AHHSDDALFIYG & IKISPKKTTVSPTN & PTNA.EFLS \\
\hline & & & \\
\hline
\end{tabular}

Fig. 5. Amino acid identity between Bunyaviridae L Proteins. INSV, NC_003625); GBNV, NC_003614; WSMoV, NC_3832; RVFV; NC_ 002043, (BUNV; NC_001925), Hantaan natavirus=6533 nt (HTNV; NC_005222) and Puumala hantavirus= 6526 nt (PUUV; AY526217). Polymerase motif (A-E) are depicted as bars. 


\begin{abstract}
TSWV-KP MLTLFGNKGSSKSARKDE-GPLVSLAKHNGNVEVSKPWSSSDE----KLALTKAMDTSKGKILLNTEGTSSFGTYE-----SDSITESEG 80 TSWV-BR01 MLTLFGNKRPSKSVMA------VLKSQNHGLLLMKSLLPGKDEGPLVSLAKHKAMDASKGKILLNIEGTSSFGTYE-----SDSITESEG 79 INSV MNSFFKSLRSSSSRELDHPRVTTTLSKQGADIVVHNPSANHNN----KEVLQRAMDSSKGKILMNNTGTSSLGTYE-----SDQISESES 81 WSMOV MYRLSNVLKPFRLSNNTNKEMVPAVKTENNKSI IVRNVSKKDI----DEAIMNKVKTANGKQYVSGIDSSILGTYSSELDTGESDVGDSS 86 GBNV MSRFSNVLESFRPSNSSNKELVPAVKKENNRSILARNVSKKDV----DSAIMNKAKTLNGKQYVSSGDSSVLGTYS-----SESAVEATS 81

* . . . . * * * * *** . .

P/D-L-X-

TSWV-KP YDLSARMIVDTNHHISNWKNDLF/GNGKQNASKVIKICPTWDSRKQYMMI SRIVIWVCPT IPNPTGKLVVALVDPN-MPSEKQVILKGQG 169 TSWV-BR01 YDLSARMIVDTNHHI SNWKNDLFVGNGKQNANKVIKICPTWDSRKQYMMI SRIVIWVCPT IPNPTGKLVVALIDPN-MPSGKQVILKGQG 168 INSV YDLSARMIVDTNHHI SSWKNDLFVGNGDKAATKI IKIHPTWDSRKQYMMI ISRIVIWI CPT I ADPDGKLAVAL IDPN-KSVNARTVLKGQG 170 WSMOV DDILSRLVVEQSTHLSNWKNDSLVGGGNDKVSFTISIMPTWNSGRRFMHI SRL ILWVVPT IPDSKNSIKVTLLDQNKMTREEKI ILSRQT 176 GBNV DDILSRLVVEQSTHLSNWKNDSL/GGNGNDKVSFT IS IMPTWNSNRRYMHI SRL I IWVVPT IPDSKNNVKASL IDPNKMTKEEK I I ISRQA 171

TSWV-KP TIADPICFVFYLNWSIPKMNNTPENCCQLHLMCSQEYKKGVSFGSVMYSWTKEFCDSPRADKDKSCMVIPLNRAIRARSQAFIEACKLIP 259 TSWV-BR01 TI TDPICFVFYLNWS IPKMNNTPENCCQLHLMCSQEYKKGVSFGSVMYSWTKEFGDSPRADKDKSCMVIPLNRAIRARSQAFIEACKLII 258 INSV SIKDPICFVFYLNWSIPKVNNTSENCVQLHLLCDQVYKKDVSFASVMYSWTKEFCDSPRADLDKSCMI IPINRAIRAKSQAFIEACKLIP 260 WSMOV SLKDPLCFIFHLNWSFPKERNTPKQCMQLNLTSDEKYAKGVSFASVMYSWVKNFCDTPIASESNTCDVIPINRAKVIKSAALEACKLMIP 266 GBNV SLKDPMCF IFHLNWSFPKERNTPKQCMQLNLTSDEKYAKGVSFASVMYSWVKNFCDTPIAAENNTCDVVPINRAKVIQSAALIEACKMIP 261

$\begin{array}{lll}\text { TSWV-KP KGNSEKQIKKQLKELSSNVVGSVGVGLGVFFGSVAQLSFD-EI-- } & 301\end{array}$ TSWV-BR01 KGNSEKQIKKQLKELSSNLERSVEEEEEGISDSVAQLSFD-E I-- 300 INSV KGNSEKQIRRQLAELSANLEKSVEEEEN. VTDNKIEISFDNEI-- $\quad 302$ WSMOV KGIGGKQLSNQIRALQKAAEKYAMEAENDADVIDVDIEMDNLLEI $\quad 311$ GBNV KGTGGKQISNQIKSLQKAAERLALEAENDDESLDVDIEMDNLLEI 306
\end{abstract}

Figure 6. Multiple alignment of the NSm protein sequence of the five tospovirus isolates. The alignment was done with the DNAMAN program. Dashes represent gaps introduced to reach optimal alignment. Perfectly conserved residues are indicated by an asterisk and highly conseved residues are indicated by dot. Data from TSWV-BR01 [NC_002050]; INSV [NC_003616]; WSMoV [NC_003841]; GBNV [NC_003620].

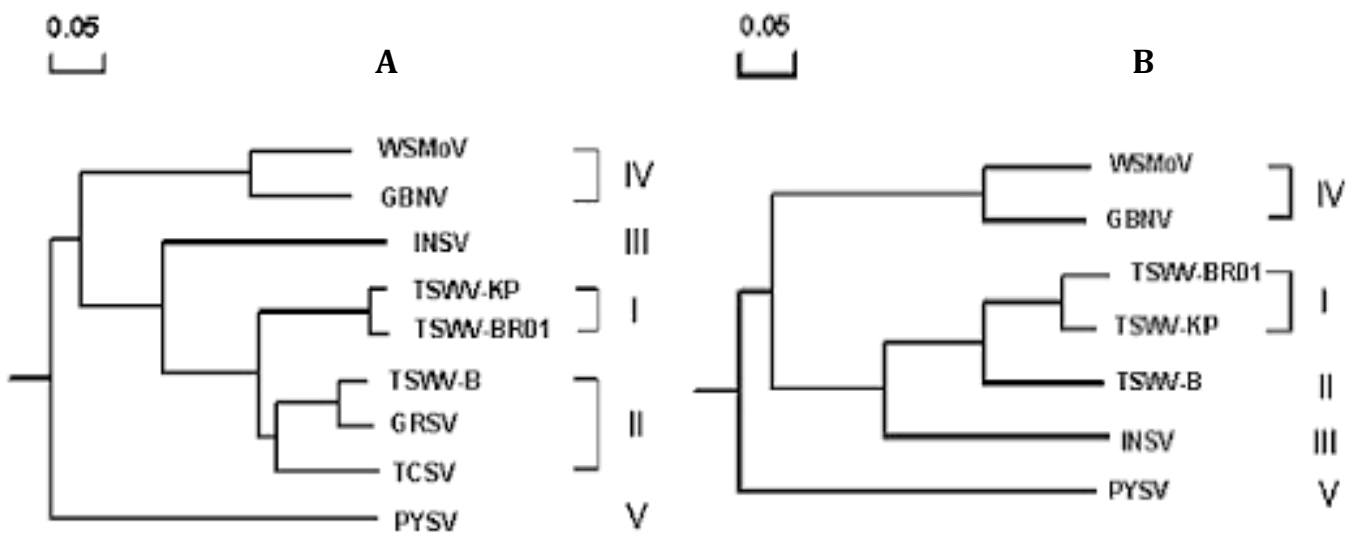

Figure 7. Phylogenic relationship among various tospovirus isolates based on the amino acid sequences of the $\mathrm{N}$ protein (A) and NSs proteins (B). The scale at the top of the figure indicate genetic distance. Roman number represented the serogroups from I to $\mathrm{V}$ of Tospovirus genus.

The TSWV-KP N protein consisted of 258 amino acids, which were 3,16 , and 17 amino acids shorter than those for the INSV [NC_003624; 261 amino acids], GBNV [NC_003919; 275 amino acids], and WSMoV [NC_003843; 274 amino acids], respectively. However, it was 12 amino acids longer than that of the PYSV
[AF013994; 246 amino acids]. The N protein of TSWV$\mathrm{KP}$, however, showed lower identity with those of other serotype III-V tospoviruses, whereas, a higher consensus in amino acid residues of the $C$ terminal region for 60 amino acids was observed between serotypes I and II. 
The TSWV-KP NSs protein sequence revealed only 34.493.1\% identity for the nucleotides and $13.3-87.9 \%$ identity for the amino acid sequences with the members of serogroups I-V (Table 2). The TSWV-KP NSs protein was $3,18,28$, and 28 amino acids longer than the respective proteins of TSWV-BR01, INSV, GBNV, and WSMoV, whereas the PYSV NSs protein was 13 amino acids longer than that of TSWV-KP.

Table 3. Identities of nucleotide sequence (nt) and amino acid (aa) of TSWV-KP S RNA and those of other tospoviruses ${ }^{a}$

\begin{tabular}{|c|c|c|c|c|c|c|c|}
\hline \multirow{2}{*}{ Virus } & \multirow{2}{*}{$5^{\prime} \mathrm{UTR}$} & \multicolumn{2}{|c|}{ NSs } & \multirow{2}{*}{ IGR } & \multicolumn{2}{|c|}{$\mathrm{N}$} & \multirow{2}{*}{$3^{\prime}$ UTR } \\
\hline & & nt & aa & & $\mathrm{nt}$ & aa & \\
\hline TSWV-BR01 & 96.6 & 93.1 & 87.9 & 89.2 & 96.4 & 98.4 & 92.2 \\
\hline TSWV-B & - & 79.3 & 81.3 & - & 77.5 & 79.8 & - \\
\hline TCSV & - & - & - & - & 76.6 & 77.5 & - \\
\hline GRSV & - & - & - & - & 76.9 & 78.7 & - \\
\hline INSV & 41.0 & 61.4 & 56.7 & 56.7 & 57.6 & 54.5 & 45.5 \\
\hline GBNV & 46.2 & 43.0 & 45.7 & 45.7 & 45.9 & 31.1 & 58.6 \\
\hline WSMoV & 49.2 & 42.2 & 49.2 & 49.2 & 46.1 & 31.5 & 52.9 \\
\hline PYSV & 52.6 & 34.4 & 35.9 & - & 38.2 & 19.9 & 72.2 \\
\hline
\end{tabular}

aThe following sequences were obtained from NCBI GenBank database. TSWV-BR01 [NC_002051], TSWV-B [L12048], TCSV [S54325], GRSV [S54327], INSV [NC_003624], GBNV [NC_003619], WSMoV [NC_003843], PYSV [AF013994].

\section{DISCUSSION}

TSWV is polyphagous on a great number of mostly herbaceous hosts. The host range is estimated to comprise up to 900 plant species within 80 families and has a worldwide distribution (Goldbach and Petter 1994). The virus causes severe yield losses in many economically important crops. However, TSWV has not been reported in pepper fields in Korea.

In this study, a strain of TSWV, named TSWV-KP, was isolated for the first time from a diseased paprika, and its properties were characterized. TSWV-KP was highly similar to the known TSWV isolates (de Avila et al., 1992; Iwaki et al., 1984; Kameyi-Iwaki et al., 1988; Law et al., 1990; Maiss et al., 1991; Yen et al., 1992). Host reactions to TSWV-KP are summarized in Table 1. Symptoms generally included local necrotic lesions, systemic mottling, leaf distortions, and stunting. Comparisons of the symptomatology of TSWV-KP and two other isolates (Chatzivassiliou 1996; Pang 1993) showed that TSWV-KP differed from TSWV-T $\mathrm{T}_{\mathrm{TH}}$ and TSWV-B, in that TSWV-KP induced only local lesions on N. glutinosa, which is a systemically infected host of TSWV-T $_{\mathrm{TH}}$ and TSWV-B. Unlike TSWV-B, which systemically infected Petunia hybrida, TSWV-KP did not systemically infect $P$. hybrida and only induced local lesions on the inoculated leaf. Tospoviruses can establish widespread systemic infections in the plants. They invade the root (Ie 1964; Kitajima 1965), stem
(Peters et al., 1991), leaves (Best and Palk 1964; Ie 1964; Kitajima 1965; Milne and de Zoeten 1967), and anthers (Ie 1973). Many of the cytopathological differences reported between tospovirus isolates relate to differences in virion maturation. Plants infected with non-defective isolates typically contain masses of single enveloped ("mature") virions clustered within swollen cisternae of the endoplasmic reticulum (ER) (Ie 1964, 1971; Kitajima 1965; Milne and de Zoeten 1967).

Some tospovirus isolates are morphologically defective or partially defective; infections of these isolates contain primarily unenveloped nucleocapsids (Ie 1982; Verkleij and Peters 1983; Resende et al., 1991 a, b; Urban et al., 1991; Kitajima et al., 1992b). Electron microscopical studies of TSWV have demonstrated that viral particles accumulate in the cisternae of the ER in the cytoplasm of infected cells (Fig. 1-B). Ultrastructural investigations of tissues infected by tospoviruses have shown that mature infections typically contain SEVs within membranous cisternae (Ie 1964, 1971; Kitajima 1965; Milne and Zoeten 1967; Francki and Grivell 1970; Milne 1970).

Time-course studies have revealed the presence of early DEVs (Milne 1970). The composition of proteins in the outer membrane has not been established, and it has been interpreted as a second viral envelope (Milne 1970 ) or as the membrane of a Golgi vesicle (Kitajima et al., 1992a). Outer envelopes are thought to fuse with host membranes and with each other, which release 
mature SEV into expanding cisternal spaces (Milne, 1970; Kitajima et al., 1992a). Fibers and fibrous structures can be found; however, the presence of filamentous inclusions in infected tissue is considerably variable, which has led to speculation that their development might depend on the stage of infection and the host (Kitajima et al., 1992a).

A large portion of the nucleocapsid protein produced during an infection is not used for producing particles but appears to be stored in large nucleocapsid aggregate (NCA) clusters. Cytoplasmic accumulations that contain $\mathrm{N}$ protein have been described in different terms as follows: dense band (Kitajima 1965), amorphous densely stained material (Milne 1970), amorphous masses (Ie 1982; Verkleij and Peters 1983), nucleocapsid aggregates (Verkleij and Peters 1983; Peters et al., 1991; de Avila 1992; Kitajima et al., 1992a; Lawson et al., 1993; Kormelink et al., 1994), dense aggregates (Resende et al., 1991a), viroplasm (Francki and Grivell 1970; Milne 1970; Francki et al., 1985; Kitajima et al., 1992a), and dense masses (de Avila et al., 1990; Peters et al., 1991).

Determination of the complete nucleotide sequence of TSWV-KP L-RNA demonstrates that TSWV is a negativestrand RNA virus. The present nucleotide sequence data confirms the previous conclusion, derived from the SRNA sequence, that TSWV should be considered as a member of Bunyaviridae (de Hann et al., 1990).

Indeed, at the ICTV meeting during the Eighth International Congress of Virology in Berlin (1990), TSWV was accepted as the first member of the newly created genus, Tospovirus, within Bunyaviridae. The TSWV-KP L-RNA segment comprises 8,917 nucleotides, which is significantly longer than the L-RNAs of Bunyamwera $(6,875 \mathrm{nt})$ and Hantaan viruses (6,530 nt) (Elliott 1989; Schmaljohn 1990).

Additional domains may be present in the gene product of TSWV L-RNA, which may reflect the adaptation of this bunyavirus to plants. TSWV-KP L-RNA contains a complementary end that is 60-64 nucleotides in length. Previously, TSWV-BR-01 strains L-RNA could be folded into a stable panhandle structure, which may be involved in the appearance of circular nucleocapsids in virus particles (Peters et al., 1991), as also found for Bunyaviridae (Raju and Kolakofsky 1989).

Moreover, these terminal sequences would play an important role in genome transcription and replication, since they contain the initiation signals for encapsidation and RNA synthesis (Krug et al., 1989; Parvin et al., 1989). TSWV-KP L-RNA contains a single ORF in the viral complementary sense, corresponding to a protein with a predicted $\mathrm{Mr}$ of $330.9 \mathrm{kDa}$. The identities in the nucleotides and amino acid sequences of the L protein exhibited $54.2-92.2 \%$ and $45.6-93.6 \%$ identity with other tospoviruses, respectively (Fig. 4).

Analysis of viral RNA species in infected plants cells indicates that this ORF is expressed by the formation of an mRNA of approximately genome length. The predicted 330.9-kDa protein encoded by TSWV-KP LRNA most probably corresponds to the viral polymerase. Comparisons of RNA polymerases from tospoviruses as well as Bunyamwera, Rift Vally fever, Hantaan, and Puumala viruses reveal the presence of amino acid sequence motifs that are present in all polymerases showing RNA template specificity and most likely form the active sites for RNA synthesis (Poch et al., 1989).

Recently, the core polymerase regions (motifs A-E) have been suggested to be directly involved in enzyme activity, based on the superimposition on to the known three-dimensional structure of HIV reverse transcriptase (Muller et al., 1994). The nucleotide sequence of TSWVKP M-RNA showed an ambisense arrangement typical for tospoviruses. The M-RNA encodes in the viral sense a nonstructural protein called NSm (301 aa); and in the viral complementary sense, a precursor of the two glycoproteins G1 and G2, which encompasses 1,134 amino acids. Between the M-RNA-encoded protein genes, a 266-nucleotide non-coding intergenic region is present. It contains a stretch rich in adenine residues followed by a stretch rich in uracil residues, thereby enabling the formation of the stable hairpin structure.

As previously discussed for other tospoviruses, this structure could be involved in the termination of transcription of subgenomic mRNAs (Kormelink et al., 1991). A conserved sequence found at the top of the tospovirus M-RNA hairpin indicates a possible function in transcription termination (Cortez et al., 2002). Whether the structural features are a requirement for the termination of transcription remains to be investigated.

Mushegian and Koonin (1993) aligned the sequences of movement proteins encoded by several plant viruses and grouped viruses according to the homology of the corresponding movement proteins. The largest plant virus movement protein group was denoted the " $30 \mathrm{~K}$ superfamily," since most of the members encode a 
movement protein of $\sim 30 \mathrm{kDa}$ molecular mass. The " $30 \mathrm{~K}$ superfamily" comprises movement proteins, which contain only one conserved region of $\sim 30$ amino acids. This region includes an aspartate residue ("D-motif") which is almost invariable among all the " $30 \mathrm{~K}$ superfamily" viruses, preceded by hydrophobic amino acids. NSm amino acid sequences available so far present the "D-motif" along with other residues typically conserved among members of the "30K superfamily" proteins (Melcher 2000), as the "P/D-L-X motif" and the "G-residue" (Fig. 6).

The adaptation of tospoviruses to plants as hosts has been made possible with the inclusion of gene coding for the potential viral movement $(\mathrm{NSm})$ protein. This has the capacity to modify plasmodesmata that simultaneously transports the viral entity through these channels (Storms et al., 1995). As this gene is of major importance for the infection cycle in plant tissues, it is likely that the determinants for the host range of tospoviruses reside within this protein. In this respect, it is interesting to note that within the currently available NSm protein sequences, a highly diverging N-terminal sequence of about 60 amino acids is present, which very well could play a role in this, reflecting the different host ranges observed for many tospoviruses.

Sequence analysis revealed that the complete nucleotide sequence of the TSWV-KP S-RNA comprised 2,991 nucleotides, i.e., 75 nucleotides longer than that of the SRNA of TSWV-BR01. This difference was mainly attributed to the elongated intergenic region of the TSWV-KP S-RNA. The $5^{\prime}$ and $3^{\prime}$ extreme ends of the TSWV-KP S-RNA were conserved and complementary, except a mismatch at nucleotide position 9 .

The same mismatch was previously observed in the SRNA of TSWV-CNPH1 (de Haan et al., 1989; de Haan et al., 1990) and in animal viruses (Bouloy 1991; Elliot 1990 ) in the family Bunyaviridae. The significance of this discrepancy is unknown. Nevertheless, conservations of the terminal sequences among tospoviruses and of the mismatch within the family Bunyaviridae indicated their possible roles in replication and encapsidation (Bouloy 1991; Elliot 1990).

From the sequence, it can be deduced that the TSWV-KP S-RNA has an ambisense gene arrangement (Fig. 3). The two ORFs were separated by an intergenic region of 571 nucleotides longer than its counterparts in TSWV-BR01. The complex and stable hairpin structure that potentially could be generated by internal base pairing of U-rich stretches with A-rich stretches of the intergenic region appears to be similar to those produced in TSWVBR01, with regard to both structure and stability.

It has been suggested that this internally base-paired structure acts as a transcription termination signal (Bouloy 1991). Traditionally, the classification of Bunyaviridae has been based mainly on serology, which results in a categorization of these viruses into serogroups and serotypes (Elliott 1990). Following this classification, and using the antigenic properties of the $\mathrm{N}$ protein, three serogroups (I to III) have thus far been recognized within Tospoviruses, a genus of Bunyaviridae (Francki et al., 1991).

The International Committee on Taxonomy of Virus Taxonomy finds it important to define criteria to delineate species and to avoid the use of less discriminative concepts such as serogroups and serotypes. Serogroup IV members-PBNV and WSMoV-are serologically distinct from the members of serogroups I, II, and III (Adam et al., 1993).

The N protein of TSWV (serogroup I) showed 77-78\% sequence identity with GRSV and TCSV (serogroup II) (de Avila et al., 1993), 55\% sequence identity with INSV (serogroup III) (de Haan et al.,, 1992), and 33-35\% sequence identity with PBNV and WSMV (serogroup IV) (Yeh and Chang 1995).

Recently, PYSV was separated into a distinct species and proposed to be included in a newly established serogroup of the genus Tospovirus based on lack of serological cross reactivity and nucleic acid hybridization with TSWV, INSV, and PBNV (Satyanarayana et al., 1996). The results of a clustering analysis of the aligned sequences of $\mathrm{N}$ and NSs proteins of tospoviruses are shown in Fig. 7. The phenograms suggest that TSWV-KP should be included into serogroup I based on $\mathrm{N}$ or NSs protein sequences.

\section{ACKNOWLEDGEMENTS}

This work was supported by a grant from 2011 Research Fund of Andong National University, North Gyeongsang province, South Korea.

\section{REFERENCES}

Adams, G., S.D. Yeh, D.V.R. Reddy and S.K. Green. 1993. The serological comparison of tospovirus isolates from Taiwan and India with Impatiens necrotic spot virus and different tomato spotted wilt virus isolates. Arch. Virol. 130:237-250.

Adkins, S., R. Quadt, T.J. Choi, P. Ahlquist and T. German. 1995. An RNA-dependent RNA polymerase 
activity associated virions of tomato spotted wilt virus, a plant and insect-infecting Bunyavirus. Virology. 207:308-311.

Best, R.P. and B.A. Palk. 1964. Electron microscopy of strain $\mathrm{E}$ of tomato spotted wilt virus and comments on its probable biosyntheses. Virology. 23:445-460.

Bouloy, M. 1991. Bunyaviridae: Genome organization and replication strategies. Adv. Virus Res. 40:235275.

Chatzivassiliou, E., I.C. Livieratos, N. Katis, A. Avgelis and D. Lykouressis. 1996. Occurrence of tomato spotted wilt virus in vegetables and ornamentals in Greece. Acta. Hort. 431:44-50.

Cho, J.D., H.S. Choi, J.S. Kim, K.H. Kim and K.S. Kim. 2003. Ultrastructural differences in mixed infections of six Turnip mosaic virus and one Ribgrass mosic virus isolates in Crucifers. Plant Pathol. J. 19:111116.

Cho, J.J., R. Mau, D. Gonsalves and W.C. Mitchell. 1986. Research weeds of tomato spotted wilt virus. Plant Dis. 70:1014-1017.

Cortez, I., A. Aires, A.M. Pereira, R. Goldbach, D. Peters and R. Kormelink. 2002. Genetic organization of Iris yellow spot virus M RNA: indications for functional homology between the Gc. glycoproteins of tospoviruses and animalinfecting bunyaviruses. Arch. Virol. 147:23132325.

De-Avila, A.C., C. Huguenot, R.O. Resende, E.W. Kitajima, R. Goldbach and D. Peters. 1990. Serological differentiation of twenty of tomato spotted wilt virus. J. Gen. Virol. 71:2801-2807.

De-Avila, A.C., P. de-Haan, R. Kormelink, R.O. Resende, R. Goldbach and D. Peters. 1992. Characterization of distinct isolate of tomato spotted wilt virus TSWV. from Impatiens $\mathrm{sp}$. In the Netherlands. $J$. Phytopathol. 134:133-151.

De-Avila, A.C., P. de-Haan, R. Kormelink, R.O. Resende, R. Goldbach and D. Peters. 1993. Classification of tospoviruses based on phylogeny of nucleoprotein gene sequences. J. Gen. Virol. 74:153-159.

De-Haan, P., R. Kormelink, R.O. Resende, F. van Poelwijk, D. Peters and R. Goldbach. 1991. Tomato spotted wilt virus L RNA encodes a putative RNA polymerase. J. Gen. Virol. 72:2207-2216.

De-Haan, P., L. Wagemakers, D. Peters and R. Goldbach. 1989. Molecular cloning and terminal sequence determination of the S RNA and M RNAs of tomato spotted wilt virus. J. Gen. Virol. 70:3469-3473.

De-Haan, P., L. Wagemakers, D. Peters and R. Goldbach. 1990. The S RNA segment of tomato spotted wilt virus has an ambisense character. J. Gen. Virol. 71:1001-1007.

De-Haan, P., A.C. de-Avila, R. Kormelink, A. Westerbroek, J.J.L. Gielen, D. Peters and R. Goldbach. 1992.. The nucleotide sequence of the S RNA of Impatiens necrotic spot virus, a novel tospovirus. FEBS Lett. 306:27-32.

Dennis, J.L. and A. Scott. 2005. The tuble-forming NSm protein from Tomato spotted wilt virus complements cell-to-cell and long-distance movement of Tobacco mosaic virus hybrids. Virology. 342:26-37.

Elliott, R.M. 1989. Nucleotide sequence analysis of the large genomic RNA segment of Bunyamwera virus, the prototype of the family Bunyaviridae. Virology. 173:426-436.

Elliott, R.M. 1990. Molecular biology of the Bunyaviridae. J. Gen. Virol. 71:501-522.

Francki, R.I.B. and C.J. Grivell. 1970. An electron microscope study of the distribution of tomato spotted wilt virus in systemically infected Datura stramonium leaves. Virology. 42:969-978.

Francki, R.I.B., R.G. Milne and T. Hatta. 1985. Tomatospotted wilt virus. In Atlas of Plant Viruses. 1:101-110. Boca Ratom: CRC Press.

Francki, R.I.B., C.M. Fauquet, D.D. Knudson and F. Brown. 1991. First report of the Bunyaviridae. Arch. Virol. Supplementum. 2:1-450.

Goldbach, R. and D. Petter. 1994. Possible causes of the emergence of tospovirus diseases. Semin. Virology. 5:113-120.

Greenough, D.R., L.L. Black and W.P. Bond. 1990. Aluminium-surfaced mulch: An approach to the control of tomato spotted wilt virus in solanaceous crops. Plant Dis. 74:805-808.

Ie, T.S. 1964. An electron microscope study of tomato spotted wilt virus in the plant cell. Neth. J. Plant Pathol. 72:114-115.

Ie, T.S. 1970. Tomato spotted wilt virus. CMI/AAB Description of plant viruses. No. 39.

Ie, T.S. 1971. Electron microscopy of developmental stages of tomato spotted wilt virus in plant cells. Virology. 2:468-479.

Ie, T.S. 1973. Tomato spotted wilt virus in the anther of 
Tropaeolum majus. Neth. J. Plant Pathol. 79: 387391.

Ie, T.S. 1982. A sap-transmissible, defective form of tomato spotted wilt virus. J. G. Virol. 59:387-391.

Iwaki, M., Y. Honda, K. Hanada, H. Tochihara, T. Yonaha, K. Hokama and T. Yokoyama. 1984. Silver mottle disease of watermelon caused by tomato spotted wilt virus. Plant Dis. 68:1006-1008.

Kameyi-Iwake, M., K. Hanada and H. Tochihara. 1988. A watermelon strain of tomato spotted wilt virus TSWV-W. and some properties of its nucleocapsid. $5^{\text {th }}$ Int. Congr. Plant Pathol.

Kitajima, E.W. 1965. Electron microscopy of vira-cabeca virus Brazilian tomato spotted wilt virus. within the host cell. Virology. 26:89-99.

Kitajima, E.W., A.C. de-Avila, R.O. Resende, R. Goldbach and D. Peters. 1992a. Comparative cytological and immunological labeling studies on different isolates of tomato spotted wilt virus. J. Submicrosc Cytol. Path. 24:1-14.

Kitajima, E.W., R.O. Resende, A.C. de-Avila, R. Goldbach and D. Peters. 1992b. Immuno-electron microscopical detection of tomato spotted wilt virus and its nucleocapsids in crude plant extract. J. Virol. Methods. 38:313-322.

Kormelink, R., P. de-Haan, C. Meurs, D. Peters and R. Goldbach. 1992. The nucleotide sequence of the $M$ RNA segment of tomato spotted wilt virus: A plant-infecting bunyavirus with two ambisense RNA segments. J. Gen. Virol. 73:2795-2804.

Kormelink, R., E.W. Kitajima, P. de-Haan, D. Zuidema, D. Peters and R. Goldbach. 1991. The nonstructural protein NSs. encoded by the ambisense S RNA segment of tomato spotted wilt virus is associated with fibrous structures in infected plant sells. Virology. 181:459-468.

Kormelink, R., M. Storms, J.V. Lent, D. Peters and R. Goldbach. 1994. Expression and subcellular location of NSm protein of tomato spotted wilt virus $\mathrm{TSWV}$., a putative viral movement protein. Virology. 200:56-65.

Krug, R.M., F.V. Alonso-Caplen, I. Julkunen and M.G. Katze. 1989. Expression and replication of the influenza virus genome. In The Influenza Viruses, pp. 89-152. Edited by Krug, R.M. New York: Plenum Press.
Laemmli, U.K. and M. Farre. 1973. Maturation of the head of bacteriophage T4. I. DNA packaging event. J. Mol. Biol. 80:575-599.

Lapido, J.L., D.E. Lesemann and R. Koenig. 1988. Host ranges, serology and cytopathology of eggplant and tomato strains of eggplant severe mottle virus, a new potyvirus from Nigeria. J. of Phytopathol. 122:359-71.

Law, M.D. and J.W. Moyer. 1990. A tomato spotted wiltlike virus with serologically distinct $\mathrm{N}$ protein. $J$. Gen. Virol. 71:933-938.

Lawson, R.H., M.M. Dienelt and H.T. Hsu. 1993. Effects of passaging a defective isolate of impatiens necrotic spot virus at different temperature. Phytopathol. 83:662-670.

Maiss, E., L. Ivanova, E. Breyel and G. Adam. 1991. Cloning and sequencing of the S RNA from a Bulgarian isolate of tomato spotted wilt virus. $J$. Gen. Virol. 72:461-464.

Melcher, U. 2000. The ' $30 \mathrm{~K}$ ' superfamily of viral movement proteins. J. Gen. Virol. 81:257-266.

Milne, R.G. and G.A. de-Zoeten. 1967. A comparison of some methods of preparation of thin sections of virus infected leaves for electron microscopy. $J$. Ultrastructural Res. 19:398-407.

Milne, R.G. 1970. An electron microscope study of tomato spotted wilt virus in sections of infected cell and in negative stain preparation. J. Gen. Virol. 6:276-276.

Mohamed, N.A. 1981. Isolation and characterization of subviral structures from tomato spotted wilt virus. J. Gen. Virol. 53:197-206.

Mohamed, N.A., J.W. Randles and R.I.B. Francki. 1973. Protein composition of tomato spotted wilt virus. Virology. 56:12-21.

Morris, T.J. and J.A. Dodds. 1979. Isolation and analysis of double stranded RNA from virus-infected plant and fungal tissue. Phytopathol. 69:854-858.

Muller, R., O. Poch, M. Delarue, D.H.L. Bishop and M. Bouloy. 1994. Rift valley fever virus L segment; correction of the sequence and possible functional role of newly identified regions conserved in RNAdependent polymerase. J. Gen. Virol. 75:13451352.

Mushegian, A.R. and E.V. Koonin. 1993. Cell-cell movement of plant viruses: insights from amino acid sequence comparisons of movement proteins 
and from analogies with cellural transport systems. Arch. Virol. 133:239-257.

Pang, S.Z., J.L. Silghtom and D. Gonsalves. 1993. The biological properties of a distinct tospovirus and sequence analysis of its S RNA. Phytopathol. 83:728-733.

Parvin, J.D., P. Palese, A. Honda, A. Ishihama and M. Krystal. 1989. Promotor analysis of influenza virus RNA polymerase. J. Virol. 63:5142-5152.

Petters, D., A.C. de-Avila, E.W. Kitajima, R.O. Resende, P. de-Haan and R. Goldbach. 1991. An overview of tomato spotted wilt virus. In virus-thrips-plant interaction of TSWV, proceeding of USDA workshop, Beltsville, U.S.A., pp. 1-14. Edited by HT Hsu and RH Lawson. Springfield: National technology information service.

Poch, O., I. Sauvaget, M. Delarue and N. Tordo. 1989. Identification of four conserved motif among the RNA-dependent polymerases encoding element. EMBO. 8:3867-3874.

Raju, R. and D. Kolakofsky. 1989. The end of la crosse virus genome and antigenome RNAs within nucleocapsids are basepaired. J. Virol. 63: 122128.

Resende, R.O., P. de-Haan, A.C. de-Avila, E.W. Kitajima, R. Kormelink, R. Goldbach and D. Peters. 1991a. Generation of enveloped and defective interfering RNA mutants of tomato spotted wilt virus by mechanical passage. J. Gen. Virol. 72:2375-2383.

Resende, R.O., E.W. Kitajima, A.C. de-Avila, R. Goldbach and D. Peters. 1991b. Defective isolates of tomato spotted wilt virus. In: Virus-thrips plant interactions of tomato spotted wilt virus. Hsu, H.T. and Lawson, R.H., eds., US Dep. Agr., Agr. Res. Serv., ARS. 87: 71-76.

Ryu, K.H., C.W. Choi, J.K. Choi and W.M. Park. 1995. Cloning of the 3 '-terminal region encoding movement and coat proteins of a Korean isolate of odontoglossum ringspot virus. Arch. Virol. 140:481-490.

Satyanarayana, T., K. Lakshminarayana-Reddy, A.S. Ratna, C.M. Deom, S. Gowda and D.V.R. Reddy. 1996. Peanut yellow spot virus: A distinct tospovirus species based on serology and nucleic acid hybridization. Ann. Appl. Biol. 129:237-245.
Schmaljohn, C.S. 1990. Nucleotide sequence of the L genome segment of Hantaan virus. Nucleic Acids Res. 18:6728.

Silva, M.S., C.R.F. Martins, I.C. Bezerra, T. Nagata, A.C. deAvila and R.O. Resende. 2001. Sequence diversity of NSm movement protein of tospoviruses. Arch. Virol. 146:1267-1281.

Sippel, A.E. 1973. Purification and characterization of adenosine triphosphate ribonucleicacid adenyltransferase from Escherichia coli. European J. Biochemistry. 37:31-40.

Storm, M.M.H., R. Kormelink, D. Peters, J. van-Lent and R. Goldbach. 1995. The non-structural NSm protein of tomato spotted wilt virus induces tubural structures in plant and insect cell. Virology. 214:485-493.

Tas, P.W.L., M.L. Boerjan and D. Peters. 1977. The structural proteins of tomato spotted wilt virus. J. Gen. Virol. 36:267-279.

Tsuda, S., K. Hanada, S. Hidaka, Y. Minobe, M. KameyaIwaki and K. Tomaru. 1992. The presence of three pairs of possibly complementary RNA species in isolated nucleocapsid material of Tomato spotted wilt virus. Ann. Phytopath. Soc. Jpn. 58:393-404.

Tsuda, S., M. Kameya-Iwaki, K. Hanada, K. Tomaru and Y. Minobe. 1996. Grouping of five Tospovirus isolates from Japan. Acta. Hort. 431:176-185.

Van-Den-Hurk, J., P.W.L. Tas and D. Peters. 1977. The ribonucleic acid of tomato spotted wilt virus. $J$. Gen. Virol. 36:81-91.

Van-Poelwijk, F., K. Boye, R. Oosterling, D. Peters and R. Goldbach. 1993. Detection of the L protein of tomato spotted wilt virus. Virology. 197:468-470.

Verkleij, F.N. and D. Peters. 1983. Characterization of a defective form of tomato spotted wilt virus. J. Gen. Virol. 64:677-686.

Yeh, S.D. and T.F. Chang. 1995. Nucleotide sequence of the $\mathrm{N}$ gene of watermelon silver mottle virus, $\mathrm{a}$ proposed new member of the genus tospovirus. Phytopathol. 85:58-64.

Yen, S.D., Y.C. Lin, Y.H. Cheng, C.L. Jin, M.J. Chen and C.C. Chen. 1992. Identification of tomato spotted wiltlike virus on watermelon in Taiwan. Plant Dis. 76:835-840. 